\title{
Comparison of Hierarchical and Non-Hierarchical Methods in Clustering Cities in Java Island using the Human Development Index Indicators year 2018
}

\author{
Alvia Rossa Damayanti $^{a}$, Arie Wahyu Wijayanto ${ }^{b}$ \\ ${ }^{a}$ Politeknik Statistika STIS, Jalan Otto Iskandardinata No. 64C, Jakarta Timur 13330, Indonesia. Email: \\ 211709532@stis.ac.id \\ ${ }^{\mathrm{b}}$ Politeknik Statistika STIS, Jalan Otto Iskandardinata No. 64C, Jakarta Timur 13330, Indonesia. Email: \\ ariewahyu@stis.ac.id
}

\section{A B S TRACT}

The Human Development Index (HDI) is a composite index to assess the developmental level of life quality in a particular region. In 2018, Java Island, which geographically has the most regencies/ municipalities in Indonesia, achieved human development with "high" status and was followed by all its regencies which have also achieved human development with "high" status. Therefore, research was carried out on how the characteristics inherent in the high HDI have been achieved in regencies on Java Island and grouping them so that it is easy to interpret regencies/ municipalities with homogeneous characteristics. This study used the hierarchical cluster method (single linkage, average linkage, and ward) and non-hierarchical cluster methods (K-Means and FCM). The results show that the best hierarchical cluster method is the average linkage method which forms four clusters where the regencies/ municipalities with the best characteristics (dimensions of education, health, and high purchasing power) are Kepulauan Seribu, Bogor, and 78 other regencies/ municipalities. Then, the best non-hierarchical method is the FCM method which forms two clusters, with a prominent characteristic is those city areas have better characteristics than district areas.

Keywords: Cluster Analysis, Agglomerative Method, K-Means, Fuzzy C-Means, Human Development Index

\section{A B S T R A K}

Indeks Pembangunan Manusia (IPM) merupakan suatu indeks komposit untuk mengevaluasi tingkat perkembangan kualitas hidup masyarakat di suatu wilayah. Pada tahun 2018, Pulau Jawa yang secara geografis memiliki kabupaten/kota terbanyak di Indonesia mencapai pembangunan manusia dengan status "tinggi" dan diikuti dengan seluruh kabupaten/kotanya yang juga telah mencapai pembangunan manusia dengan status "tinggi". Oleh karena itu, dilakukan penelitian tentang bagaimana karakteristik yang melekat pada tingginya IPM yang telah dicapai pada kabupaten/kota di Pulau Jawa serta dilakukan pengelompokkan agar mudah dalam menginterpretasikan kabupaten/kota yang memiliki karakteristik homogen. Dalam penelitian ini digunakan metode klaster hirarki (single

* Corresponding author.

Alamat e-mail: 211709532@stis.ac.id 
linkage, average linkage, dan ward) dan metode klaster non hirarki (K-Means dan FCM). Hasilnya menunjukkan bahwa metode klaster hirarki terbaik adalah metode average linkage yang membentuk empat buah klaster di mana kabupaten/kota dengan karakteristik terbaik (dimensi pendidikan, kesehatan, dan daya beli yang tinggi) adalah Kepulauan Seribu, Bogor, dan 78 kabupaten/kota lainnya. Kemudian, metode non hirarki terbaik adalah metode FCM yang membentuk dua klaster, dengan karakteristik yang menonjol adalah wilayah kota memiliki karkateristik yang lebih baik dibandingkan wilayah kabupaten.

Keywords: Analisis Klaster, Aglomerative Method, K-Means, Fuzzy C-Means, Indeks Pembangunan Manusia

Diserahkan: 10-12-2020; Diterima: 26-12-2021;
Doi: https://doi.org/10.29303/emj.v4i1.89

\section{Pendahuluan}

Suatu negara pada umumnya menginginkan melakukan pembangunan yang baik sehingga masyarakat dapat mencapa kesejahteraan. Pada jaman dahulu kesejahteraan seringkali hanya dipandang dari segi ekonomi. Hingga pada tahun 1991, Bank Dunia menyatakan bahwa tantangan utama pembangunan manusia muncul untuk memperbaiki kualitas kehidupan. Artinya, tingkat pertumbuhan ekonomi yang tinggi yang berhasil dicapai oleh suatu negara belum tentu bisa berhasil dalam memperbaiki taraf hidup sebagaian besar penduduknya. Oleh karena itu, muncullah konsep Indeks Pembangunan Manusia yang digunakan untuk mengukur kesejahteraan manusia dari dimensi pendidikan, kesehatan, dan daya beli.

Di Indonesia, IPM sudah dihitung sejak tahun 1996 dan dilakukan secara berkala. Menurut publikasi BPS (2019), IPM Indonesia mencapai 71,39 dan meningkat sebesar 0,58 dari tahun sebelumnya. Sehingga pada tahun 2018 menjadikan Indonesia berstatus pembangunan manusia kategori "tinggi". Jika ditelusuri lebih jauh ke dalam kabupaten/kota di Indonesia, di antara 23 kabupaten/kota yang berstatus "sangat tinggi", sebagian besar berada di Pulau Jawa. Kemudian, peningkatan status pembangunan manusia pada 2017 ke 2018 di seluruh kabupaten/kota di Pulau Jawa menunjukkan bahwa tidak ada wilayah dengan status pembangunan manusia "rendah lagi". Hal ini merupakan prestasi yang baik bagi Pulau Jawa dan bisa dijadikan acuan untuk pulau lainnya di Indonesia. Meski begitu, tinggi rendahnya IPM hanya ditunjukkan melalui indeks komposit, dan tidak ditunjukkan secara detail indikator IPM apa saja yang dominan berkontribusi dalam penyusunan IPM.

Permasalahan utama yang dibahas dalam penelitian ini adalah menguraikan karakteristik kabupaten/kota di Pulau Jawa yang seluruhnya masuk dalam kategori pembangunan berstatus tinggi, berdasarkan indikator penyusun IPM melalui analisis klaster.

Melalui penelitian ini diharapkan dapat memberi manfaat di masa mendatang. Adapun tujuan dari penelitian ini di antaranya:
- Membandingkan metode pengelompokkan hirarki dengan metode non hirarki. Metode hirarki diwakilkan dengan metode single linkage, metode average linkage, dan metode ward. Sedangkan metode non hirarki diwakilkan dengan metode K-Means dan Fuzzy C-Means dan diterapkan pada seluruh kabupaten/kota dengan menggunakan indikator Indeks Pembangunan Manusia tahun 2018.

- Mengetahui karakteristik pada klaster kabupaten/kota di Pulau Jawa yang terbentuk.

\section{Metodologi}

Data yang digunakan dalam penelitian ini adalah data sekunder yang diperoleh melalui publikasi BPS Provinsi D.I. Yogyakarta, Jawa Barat, Jawa Tengah, Jawa Timur, dan Jawa Barat dalam angka tahun 2019 mengenai indikator Indeks Pembangunan Manusia. Dataset yang digunakan terdiri dari 129 kabupaten/kota dan lima variabel.

Pada penelitian ini, dilakukan analisis secara deskriptif maupun inferensia. Dalam analisis inferensia digunakan metode analisis klaster metode hirarki dan non hirarki yang kemudian masingmasing dipilih metode terbaik. Analisis deskriptif digunakan dalam melakukan profiling hasil analisis klaster yang terbentuk.

\subsection{Principal Component Analysis}

Menurut Johnson dan Wichern (2007), Principal Component Analysis (PCA) digunakan untuk mengatasi adanya multikolinearitas. Prinsip utama dalam PCA adalah adanya korelasi yang tinggi antarvariabel shingga variabel-variabel tersebut dapat dreduksi. PCA dapat dilakukan dengan cara menghilangkan korelasi antarvariabel bebas melalui transformasi variabel bebas asal ke variabel bebas baru yang tidak berkorelasi sama sekali atau sering disebut sebagai pricncipal component. Sebelum melakukan PCA, dilakukan pengkuran nilai Measure of Sampling Adequency (MSA). PCA dapat dilanjutkan ketika nilai MSA masing-masing variabel $>0,5$ (menunjukkan bahwa variabel bisa diprediksi dan bisa dianalisis lebih lanjut). Kemudian untuk 
menentukan banyak komponen utama bisa digunakan scree plot (ketika titik kurva tidak lagi menurun tajam atau mulai melandai) atau menggunakan proporsi kumulatif varians terhadap total varians.

\subsection{Analisis Klaster}

Analisis klaster merupakan salah satu metode objek mining yang bersifat tanpa latihan (unsupervised analysis). Analisis klaster merupakan salah satu analisis peubah ganda (multivariate analysis) yang dapat digunakan untuk mengklasterkan data observasi ataupun variabel-variabel ke dalam klaster sedemikian rupa sehingga masing-masing klaster bersifat himigen sesuai dengan faktor yang digunakan untuk melakukan pengklasteran dan heterogen antarklaster yang terbentuk (Gudono, 2011).

Adapun ciri-ciri klaster adalah:

1. Homogenitas (kesamaan) yang tinggi antar anggota dalam satu klaster (within-cluster)

2. Heterogenitas (ketidaksamaan) yang tinggi antarklaster yang satu dengan klaster lainnya (between-cluster)

Proses pembentukan klaster dapat dilakukan dengan dua cara, yaitu metode hiraki dan non hirarki. Dalam metode hirarki belum ada informasi jumlah klaster yang akan dipilih. Metode hirarki secara umum dibedakan menjadi metode aglomeratif (penggabungan) dan divisif (pemecahan). Metode aglomeratif terdiri dari metode linkage (single linkage, complete linkage, dan average), variance (ward), dan centroid. Sedangkan pada metode non hirarki bertujuan untuk mengelompokan $\mathrm{n}$ objek ke dalam $\mathrm{k}$ klaster $(\mathrm{k}<\mathrm{n})$, di mana nilai $\mathrm{k}$ telah ditentukan sebelumnya. Metode non hirarki terdiri dari sequential threshold, parallel threshold, dan optimizing partition. Metode K-Means dan Fuzzy CMeans sendiri masuk ke dalam metode non hirarki.

\subsection{Metode Single Linkage}

Metode ini dikenal dengan nama pendekatan tetangga terdekat dan didasarkan pada jarak minimum antarklaster. Dimulai dengan dua objek yang dipisahkan dengan jarak paling pendek maka keduanya akan ditempatkan pada klaster pertama, dan seterusnya.

$$
d_{(i j) k}=\min \left(d_{I K}, d_{J K}\right)
$$

Besaran $d_{I K}$ dan $d_{J K}$ adalah jarak terpendek antara klaster-klaster $I$ dan $K$ dan juga klaster-klaster $J$ dan $K$.
Tahap melakukan metode single linkage adalah sebagai berikut.

1. Menemukan jarak minimum dalam $D=\left\{d_{i j}\right\}$.

2. Menghitung jarak antar klaster yang telah dibentuk pada langkah 1 dengan objek lainnya.

3. Dari algoritma di atas jarak-jarak antara objek $I$ dan $J$ dan klaster $K$.

\subsection{Metode Average Linkage}

Metode ini didasarkan pada jarak rata-rata antarobservasi. Pengelompokkan dimulai dari pasangan observasi dengan jarak paling mendekati jarak rata-rata.

$$
d_{(i j) k}=\frac{\sum_{a} \sum_{b} d_{a b}}{N_{I J} N_{K}}
$$

Keterangan:

$d_{a b} \quad$ : jarak antara obyek i pada klaster $I J$ dan obyek $b$ pada klaster $K$

$N_{I J} \quad$ : jumlah item pada klaster $I J$

$N_{K} \quad$ : jumlah item pada klaster $I J$ dan $K$

Tahap melakukan metode average linkage adalah sebagai berikut (Johnson dan Wichern, 2007).

1. Mencari dua objek yang memiliki kesamaan paling dekat pada matriks similaritas. Misal kedua objek itu adalah objek $I$ dan $J$.

2. Menggabungkan objek $I$ dan $J$ dalam satu klaster.

3. Penggabungan kedua merupakan penggabungan klaster dengan klaster lain yang memiliki kesamaan paling dekat, misal klaster $K$.

4. Mengulangi kembali langkah 3 sebanyak $N-1$ kali, di mana $N$ adalah jumlah objek

\subsection{Metode Ward}

Metode ini bertujuan untuk memeroleh klaster yang memiliki varian dalam klaster sekecil mungkin. Dalam mengelompokkan objek didasarkan pada kenaikan sum square error (SSE). Pada tiap tahap, dua klaster yang memiliki kenaikan SSE paling kecil maka akan digabungkan.

$$
S S E=\sum_{j=1}^{N}\left(x_{j}-\bar{x}\right)^{\prime}\left(x_{j}-\bar{x}\right)
$$

Keterangan:

$x_{j} \quad$ : nilai atau data dari objek ke-j

$\overline{\mathrm{x}} \quad$ : rata-rata nilai dari keseluruhan objek dalam klaster

Tahap melakukan metode ward adalah sebagai berikut (Johnson dan Wichern, 2007).

1. Dimulai dari setiap objek dianggap sebagai sebuah klaster tersendiri, maka didapat $N$ klaster yang mempunyai satu objek. Pada tahap ini SSE bernilai nol. 
2. Menghitung SSE untuk setiap kombinasi dua pasang klaster dari $N$ klaster, lalu memilih dua pasang klaster yang memiliki nilai SSE terkecil untuk digabungkan menjadi satu klaster. Secara sistematik, $N$ klaster akan berkurang 1 pada setiap tahap $(N-1)$.

3. Membuat kombinasi dua pasang klaster baru yang terdiri dari satu klaster yang telah terbentuk dan klaster yang lain, lalu menghitung nilai SSE kembali. Memilih dua pasang klaster yang memiliki nilai SSE terkecil untuk digabungkan menjadi satu klaster.

4. Mengulangi langkah 3 sampai semua objek bergabung menjadi satu klaster.

\subsection{Metode K-Means}

Metode K-Means digunakan sebagai alternatif metode klaster untuk data dengan ukuran yang lebih besar. Hal ini dikarenakan metode ini memiliki kecepatan yang lebih tinggi jika dibandingkan dengan metode hirarki (Johnson dan Wicherr, 2007). Langkah-langkah metode K-Means adalah sebagai berikut (Johnson dan Wichern, 2007).

1. Menentukan nilai $\mathrm{k}$ awal sebagai jumlah klaster yang ingin dibentuk (menggunakan Elbow Plot, ditentukan pada titik ketika garis sikunya berbelok (landai)).

2. Menentukan k centroid (titik pusat klaster awal secara acak).

3. Hitung jarak setiap data ke masing-masing centroid menggunakan rumus korelasi antardua objek yaitu jarak Euclidean.

$$
d_{i j}=\sqrt{\sum_{k=1}^{p}\left(x_{i k}-x_{j k}\right)^{2}}
$$

Keterangan:

$d_{i j}$ : jarak objek ke- $i$ dan objek ke-j

$p:$ jumlah klaster

$x_{i k}$ : data dari subjek ke- $i$ pada variabel ke- $k$

$x_{j k}$ : data dari subjek ke-j pada variabel ke- $k$

4. Kelompokkan setiap data berdasarkan jarak terdeka antara data dengan centroid-nya.

5. Tentukan posisi centroid baru dengan mengitung nilai rata-rata dari data yang ada pada kelompok centroid yang sama.

$$
C_{k}=\left(\frac{1}{n_{k}}\right) \sum d_{i}
$$

Dengan $n_{k}$ adalah jumlah data dalam klaster $\underline{\mathrm{k}}$ dan $\mathrm{d}_{\mathrm{i}}$ adalah data dalam klaster $k$.

6. Kemudian kembali ke langkah 3 jika posisi centroid baru dengan centroid lama tidak sama.

\subsection{Metode Fuzzy C-Means (FCM)}

Dalam metode FCM, objek data dapat menjadi milik lebih dari satu klaster, dengan nilai keanggotaan tertentu. FCM dapat menentukan keanggotaan dan masing-masing secara iteratif memperbarui nilai keanggotaan dari objek data dengan jumlah klaster yang ditentukan. Langkah-langkah metode FCM adalah sebagai berikut.

1. Menentukan jumlah klaster menggunakan silhouette plot.

2. Membangkitkan derajat keanggotaan awal.

3. Menghitung pusat klaster, memperbarui nilai keanggotaan, dan menghitung fungsi objektif iterasi ke-t.

4. Jika $\left|P_{t}-P_{t-1}\right|<\varepsilon$, maka iterasi berhenti.

\subsection{Validitas Metode Hirarki}

Untuk melakukan validitas pada metode hirarki digunakan uji validitas cophentic. Menurut Kassambara (2017), untuk mengukur seberapa baik dendogram yang dihasilkan oleh fungsi hclust() mencerminkan data, salah satu caranya adalah menghitung koefisien korelasi cophentic. Semakin mendekati satu berarti semakin akurat klaster dapat merefleksikan data. Nilai di atas 0,75 dianggap sudah baik dalam merefleksikan data.

\subsection{Validitas Metode Non Hirarki}

Menurut Gordon (1999) salah satu validasi dalam analisis klaster adalah menggunakan validasi internal. Validasi internal yaitu proses yang menghitung hubungan antara struktur klaster yang diperoleh dengan data itu sendiri. Data yang digunakan untuk proses klaster dan validasi adalah sama. Pendekatan ini mempunya beberapa macam indeks kualitas internal yang digunakan untuk menentukan jumlah klaster yang optimal yaitu indeks konektivitas, indeks daunn, dan silhouette.

\subsection{Variabel yang Digunakan}

Variabel yang digunakan dalam melakukan pengelompokkan kabupaten/kota berdasarkan indikator IPM adalah sebagai berikut.

Tabel 1- Variabel Penelitian

\begin{tabular}{lll}
\hline \multicolumn{1}{c}{ Variabel } & \multicolumn{1}{c}{ Definisi } & Skala \\
\hline & $\begin{array}{l}\text { Biaya yang } \\
\text { dikeluarkan untuk }\end{array}$ & \\
Pengeluaran per & $\begin{array}{l}\text { konsumsi semua } \\
\text { anggota rumah }\end{array}$ & Rasio \\
kapita $\left(X_{l}\right)$ & $\begin{array}{l}\text { tangga selama } \\
\text { sebulan dibagi }\end{array}$ & \\
&
\end{tabular}




\begin{tabular}{lll}
\hline \multicolumn{1}{c}{ Variabel } & \multicolumn{1}{c}{ Definisi } & Skala \\
\hline & $\begin{array}{l}\text { dengan banyaknya } \\
\text { anggota rumah } \\
\text { tangga. }\end{array}$ & \\
& $\begin{array}{l}\text { Rata-rata jumlah } \\
\text { tahun yang ditempuh } \\
\text { penduduk berumur }\end{array}$ & \\
Rata-rata lama & $\begin{array}{l}\text { 15 tahun ke atas } \\
\text { untuk menempuh }\end{array}$ & Rasio \\
sekolah $\left(X_{2}\right)$ & $\begin{array}{l}\text { semua jenjang } \\
\text { pendidikan yang } \\
\text { pernah dijalani. }\end{array}$ & \\
\hline $\begin{array}{l}\text { Umur harapan } \\
\text { hidup saat lahir } \\
\left(X_{3}\right)\end{array}$ & $\begin{array}{l}\text { Rata-rata perkiraan } \\
\text { banyak tahun yang } \\
\text { dapat ditempuh oleh } \\
\text { seseorang sejak lahir. }\end{array}$ & Rasio \\
\hline & $\begin{array}{l}\text { Lamanya sekolah } \\
\text { (dalam tahun) yang } \\
\text { diharapkan akan } \\
\text { dirasakan oleh anak } \\
\text { pada umur tertentu di } \\
\text { masa mendatang. }\end{array}$ & Rasio \\
Harapan lama & \\
sekolah $\left(X_{4}\right)$ & $\begin{array}{l}\text { Banyaknya jumlah } \\
\text { dokter di suatu } \\
\text { kabupaten/kota. }\end{array}$ & Rasio \\
\hline$\left.X_{5}\right)$ & & \\
\hline
\end{tabular}

\section{Analisis dan Pembahasan}

\subsection{Pengujian Asumsi}

\section{Asumsi Non-Multikolinearitas}

Dalam melakukan analisis klaster asumsi nonmultikolinearitas tidak dapat diabaikan karena jumlah observasi yang tidak terlalu besar. Berdasarkan pengolahan dengan aplikasi $\mathrm{R}$ didapatkan korelasi antar variabel sebagai berikut.

Tabel 2 - Korelasi Antar Variabel

\begin{tabular}{cccccc}
\hline & $X_{1}$ & $X_{2}$ & $X_{3}$ & $X_{4}$ & $X_{5}$ \\
\hline$X_{1}$ & 1 & 0,819 & 0,311 & 0,605 & 0,737 \\
\hline$X_{2}$ & 0,819 & 1 & 0,417 & 0,717 & 0,517 \\
\hline$X_{3}$ & 0,311 & 0,417 & 1 & 0,316 & 0,275 \\
\hline$X_{4}$ & 0,605 & 0,717 & 0,316 & 1 & 0,389 \\
\hline$X_{5}$ & 0,737 & 0,517 & 0,275 & 0,389 & 1 \\
\hline
\end{tabular}

Pada Tabel 2, terlihat bahwa masih banyak korelasi yang tinggi $(>0,7)$ antarvariabel bebas. Yaitu pada variabel $X_{1}$ dan $X_{2}$ serta variabel $X_{2}$ dan $X_{4}$. Selain itu, nilai p-value pada Bartlett's Test of Sphercity, menunjukkan hasil yang signifikan menolak $\mathrm{H}_{0}$. Hal ini mengindikasikan adanya multikolinearitas antarvariabel. Maka dari itu asumsi multikolinearitas dalam analisis klaster tidak terpenuhi. Sehingga, dilakukan Principal Component Analysis (PCA) terlebih dahulu untuk mengatasi masalah multikolinearitas. Selain itu, karena satuan variabel berbeda, maka dilakukan standarisasi data sebelum melakukan PCA.

\section{Principal Component Analysis (PCA)}

Tahapan selanjutnya adalah pembentukan PCA, berdasarkan output aplikasi $R$, proporsi kumulatif varians menggunaan tiga komponen utama mencapai $91,83 \%$, sehingga dalam penelitian ini digunakan tiga buah komponen utama sebagai pembentuk klaster nantinya. Berikut ini persamaan komponen utama yang terbentuk.

$$
\begin{gathered}
P C 1=-0,52 X_{1}-0,51 X_{2}-0,29 X_{3}-0,44 X_{4}-0,43 X_{5} \\
P C 2=0,26 X_{1}+0,004 X_{2}-0,91 X_{3}-0,02 X_{4}+0,33 X_{5}
\end{gathered}
$$

$$
P C 3=0,12 X_{1}-0,27 X_{2}+0,28 X_{3}-0,64 X_{4}+0,65_{5}
$$

Persamaan (7), (8), dan (9) digunakan untuk mencari nilai komponen utama. Skor tersebut yang dijadikan dasar pengelompokkan kabupaten/kota di Pulau Jawa tahun 2018 menggunakan metode hirarki maupun metode non hirarki, karena ketiga komponen tersebut sudah bebas dari multikolinearitas.

\subsection{Analisis Klaster Hirarki}

Dalam melakukan analisis klaster hirarki digunakan tiga metode, yaitu single linkage, average linkage, dan ward dengan menggunakan jarak Euclidean. Berdasarkan pengujian dengan aplikasi R didapatkan kelompok klaster dengan metode single linkage, average linkage, dan ward yang hasil dendogramnya adalah sebagai berikut.

\section{Metode Single Linkage}

Pada metode single linkage, terbentuk empat buah klaster di mana jumlah masing-masing objek pada klaster satu samapai dengan empat berturut-turut adalah 112, 1, 5, dan 1 kabupaten/kota. Berikut adalah dendogram dari pengelompokkan menggunakan metode single linkage. 


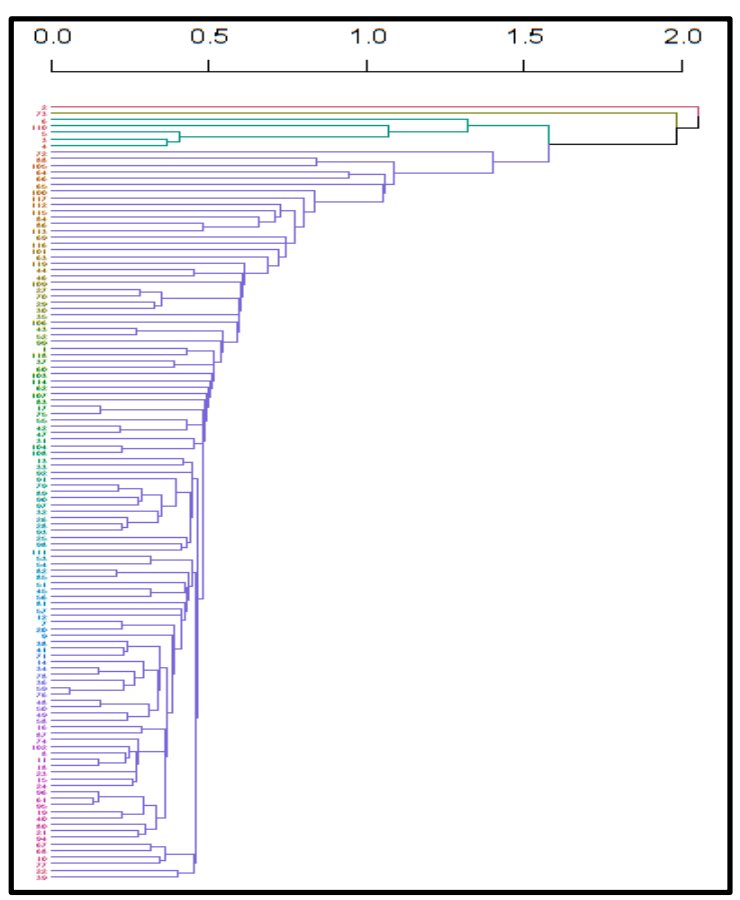

Gambar. 1 - Dendogram hasil pengelompokkan dengan metode single linkage

\section{Metode Average Linkage}

Pada metode average linkage, terbentuk empat buah klaster di mana jumlah masing-masing objek pada klaster satu samapai dengan empat berturut-turut adalah 81, 6, 31, dan 1 kabupaten/kota. Berikut adalah dendogram dari pengelompokkan menggunakan metode averae linkage.

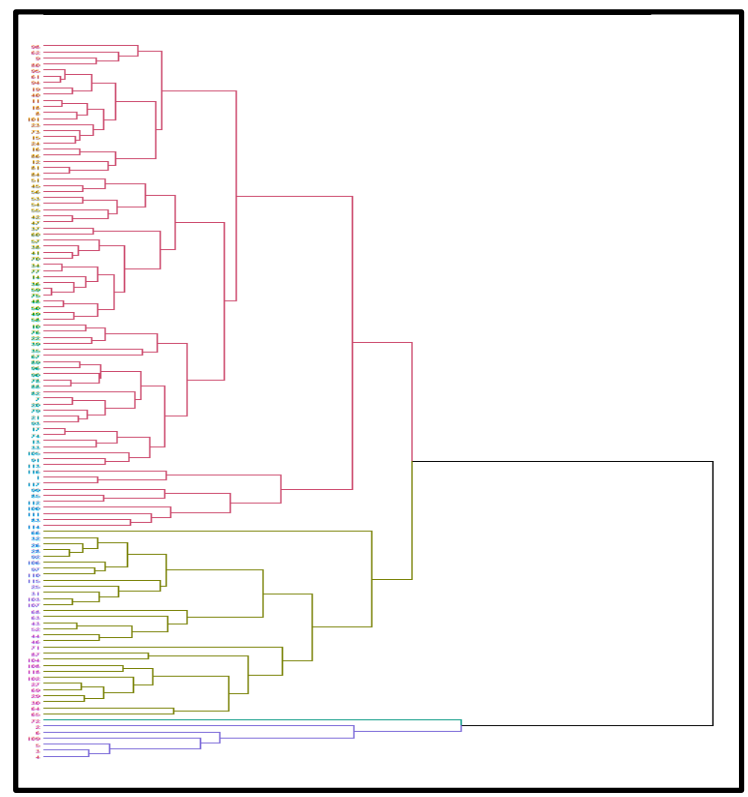

Gambar. 2 - Dendogram hasil pengelompokkan dengan metode average linkage

\section{Metode Ward}

Pada metode ward, terbentuk empat buah klaster di mana jumlah masing-masing objek pada klaster satu samapai dengan empat berturut-turut adalah 41,6 , 50, dan 22 kabupaten/kota. Berikut adalah dendogram dari pengelompokkan menggunakan metode ward.

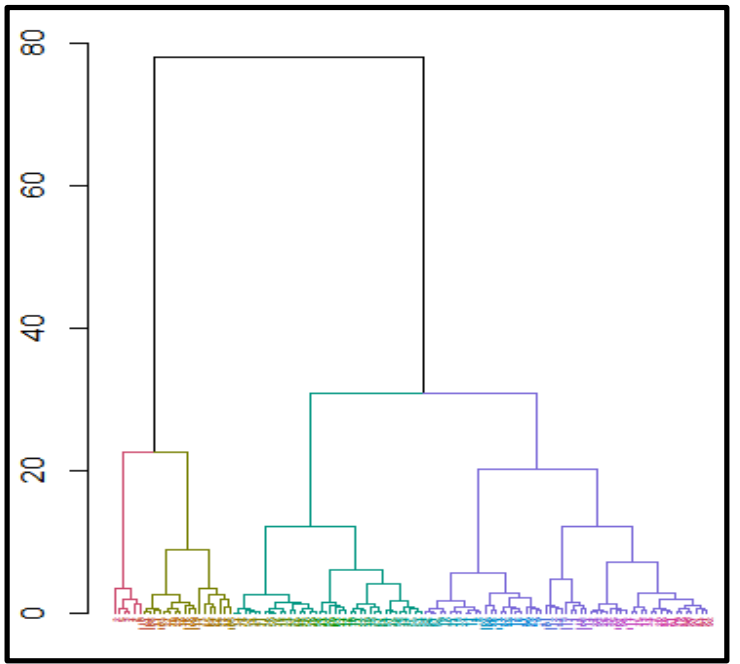

Gambar. 3 - Dendogram hasil pengelompokkan dengan metode ward

\section{Validitas Metode Hirarki}

Selanjutnya adalah uji validitas metode klaster hirarki untuk mengukur metode mana yang terbaik dalam membentuk dendogram dalam mencerminkan data. Pengujian ini dilakukan dengan menghitung koefisien korelasi cophentic. Hasilnya adalah sebagai berikut.

Tabel 3 - Nilai koefisien korelasi cophentic

\begin{tabular}{cc}
\hline Metode & Koefisien Korelasi Cophentic \\
\hline Single linkage & 0,797 \\
\hline Average linkage & 0,816 \\
\hline Ward & 0,672 \\
\hline
\end{tabular}

Nilai korelasi cophentic yang mendekati 1 berarti semakin akurat klaster dapat mencerminkan data. Berdasarkan Tabel 3, menunjukkan bahwa metode average linkage terpilih menjadi model analisis klaster hirarki terbaik dalam penelitian ini dalam merefelksikan data. Selanjutnya, untuk menentukan jumlah klaster maksimal terbaik yang akan dibentuk dengan metode average linkage digunakan package $\mathrm{NbClust}$ (), hasilnya diperoleh jumlah klaster terbaik adalah menggunakan empat buah klaster. 


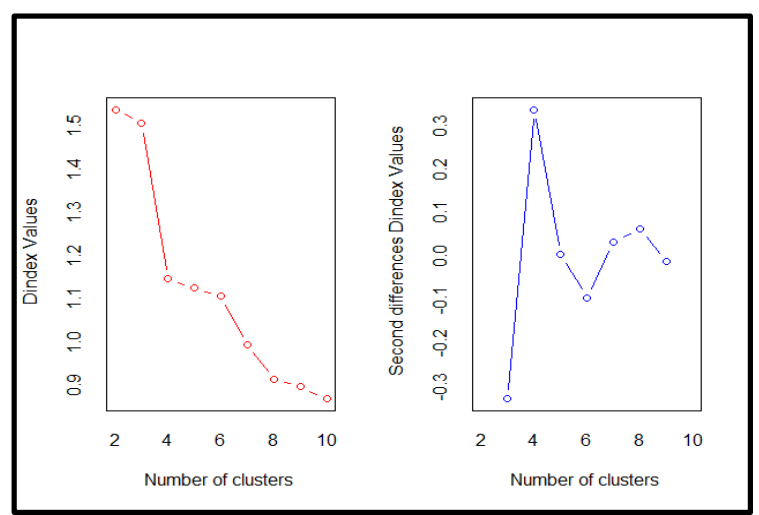

Gambar. 4 - Penentuan jumlah klaster

Tabel 4 - Hasil pengelompokkan dengan metode average linkage

\begin{tabular}{|c|c|}
\hline Klaster & Kabupaten/Kota \\
\hline \multirow{28}{*}{ Klaster 1} & Kep. Seribu, Bogor, Sukabumi, \\
\hline & Cianjur, Bandung, Garut, \\
\hline & Tasikmalaya, Ciamis, Kuningan, \\
\hline & Cirebon, Majalengka, Sumedang, \\
\hline & Indramayu, Subang, Purwakarta, \\
\hline & Karawang, Bekasi, Bandung \\
\hline & Barat, Pangandaran, Kota Banjar, \\
\hline & Cilacap, Banyumas, Purbalingga, \\
\hline & Banjarnegara, \\
\hline & Purworejo, \\
\hline & Magelang, Boyolali, Wonogiri, \\
\hline & Sragen, Grobogan, Blora, \\
\hline & Rembang, Pati, Jepara, Demak, \\
\hline & Semarang, Temanggung, Kendal \\
\hline & Tegal, Brebes, Kota Tegal, \\
\hline & Gunung Kidul, Pacitan, \\
\hline & Trenggalek, \\
\hline & Tulungagung, Blitar, Kediri, \\
\hline & Malang, Lumajang, Jember, \\
\hline & Banyuwangi, \\
\hline & Situbondo, Probolinggo, \\
\hline & Pasuruan, Mojokerto, Jombang, \\
\hline & $\begin{array}{l}\text { Nganjuk, Madiun, Ngawi, } \\
\text { Bojonegoro, Tuban, Lamongan, }\end{array}$ \\
\hline & Bangkalan, Sampang, \\
\hline & Pamekasan, Sumenep, Kota \\
\hline & Probolinggo, Pandeglang, Lebak, \\
\hline & Tangerang, $\quad$ Serang, Kota \\
\hline & $\begin{array}{l}\text { Cilegon, Kota Serang, dan Kota } \\
\text { Tangerang Selatan. }\end{array}$ \\
\hline & Kota Jakarta Selatan, Kota \\
\hline & Jakarta Timur, Kota Jakarta \\
\hline Klaster 2 & Pusat, Kota Jakarta Barat, Kota \\
\hline & Jakarta Utara, Kota Surabaya. \\
\hline Klaster 3 & Kota Bogor, Kota Sukabumi, \\
\hline Naster 5 & Kota Bandung, Kota Cirebon, \\
\hline
\end{tabular}

\begin{tabular}{ll}
\hline & Kota Bekasi, Kota Depok, Kota \\
& Cimahi, Kota Tasikmalaya, \\
& Klaten, Sukoharjo, Karanganyar, \\
& Kudus, Kota Magelang, Kota \\
& Surakarta, Kota Salatiga, Kota \\
& Pekalongan, Kulon Progo, \\
& Bantul, Sleman, Sidoarjo, \\
& Magetan, Gresik, Kota Kediri, \\
& Kota Blitar, Kota Malang, Kota \\
& Pasuruan, Kota Mojokerto, Kota \\
& Madiun, Kota Batu, Kota \\
Tangerang, Kota Semarang \\
\hline Klaster 4 & Kota Yogyakarta \\
\hline
\end{tabular}

Dari pembentukan kelompok kabupaten/kota dengan metode average linkage, masing-masing jumlah anggota dalam klaster satu hingga klaster empat berturut-turut adalah 81 kabupaten/kota, 6 kabupaten/kota, 31 kabupaten/kota, dan 1 kabupaten/kota. Kota Yogakarta berdiri sendiri dalam sebuah klaster. Pada umumnya, kabupaten dan kota di Jawa Barat, Jawa Tengah, dan Jawa Timur berkumpul pada satu klaster.

\section{Profiling Hasil Analisis Klaster Hirarki}

Berdasarkan pengelompokkan dengan metode average linkage didapatkan empat buah klaster. Berikut ini merupakan tabel rata-rata masing-masing indikator dari komponen utama yang telah ditransformasi kembali sesuai dengan data sebelumnya.

Tabel 5 - Nilai rata-rata setiap indikator IPM dalam klaster

\begin{tabular}{cccccc}
\hline Klaster & $\boldsymbol{X}_{\boldsymbol{I}}$ & $\boldsymbol{X}_{\mathbf{2}}$ & $\boldsymbol{X}_{\mathbf{3}}$ & $\boldsymbol{X}_{\boldsymbol{4}}$ & $\boldsymbol{X}_{\boldsymbol{5}}$ \\
\hline 1 & 10145,6 & 7,7 & 71,6 & 12,5 & 229,4 \\
\hline 2 & 18878,8 & 11 & 73,8 & 13,4 & 3009 \\
\hline 3 & 13225,4 & 9,8 & 74,1 & 14,1 & 452,6 \\
\hline 4 & 18629 & 11,4 & 74,5 & 17,1 & 2515 \\
\hline
\end{tabular}

Berdasarkan Tabel 5, dapat dianalisa bahwa klaster ke empat yaitu Kota Yogyakarta memiliki karakteristik dengan tiga rata-rata variabel tertinggi jika dibandingkan klaster lainnya. Ketiga variabel tersebut adalah rata-rata lama sekolah $\left(\mathrm{X}_{2}\right)$, umur harapan hidup $\left(\mathrm{X}_{3}\right)$, dan harapan lama sekolah $\left(\mathrm{X}_{4}\right)$. Variabel yang merujuk pada pendidikan ini sejalan dengan kondisi Kota Yogyakarta yang notabane-nya adalah kota pelajar di Indonesia. Sedangkan klaster yang seluruh rata-rata variabelnya rendah terdapat pada klaster pertama yang terdiri dari Kepulauan Seribu, Bogor, Sukabumi, Cianjur, dan 76 
kabupaten/kota lainnya. Klaster pertama tentu memiliki susunan karakteristik variabel terendah jika dibandingkan dengan klaster dua dan klaster tiga. Klaster dua terdiri dari Kota Jakarta dan Kota Surabaya yang memiliki fasilitas pendidikan, kesehatan, dan biaya hidup yang lebih tinggi. Begitu pula pada klaster tiga yang terdiri dari Kota Semarang, Kota Madiun, Kota Megelang, dan 28 kabupaten/kota lainnya. Jika dilihat berdasarkan nilai rata-rata keseluruhan variabel, maka rata-rata tertinggi adalah klaster ke empat dan rata-rata terendah adalah klaster pertama.

\subsection{Analisis Klaster Non Hirarki}

Analisis klaster metode non hirarki yang digunakan adalah metode $K$-Means dan Fuzzy $C$ Means. Di mana jumlah klaster optimum yang akan digunakan terlebih dahulu ditentukan.

\section{Metode K-Means}

Penentuan jumlah klaster optimam dalam metode ini menggunakan Elbow Plot. Jumlah klaster optimum ditentukan berdasarkan titik sebelum kurva melandai dan setelah penurunan tajam. Berdasarkan gambar berikut dihasilkan jumlah klaster optimum adalah empat.

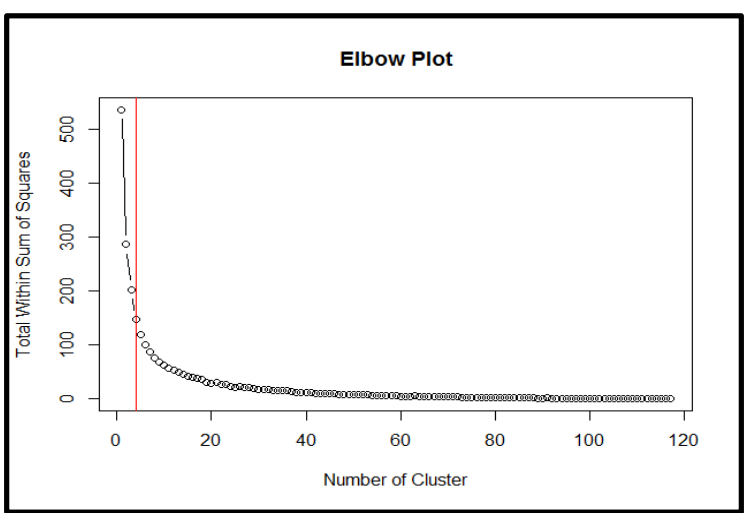

Gambar. 5 - Elbow Plot

Pengelompokkan dengan metode K-Means menunjukkan terdapat empat kelompok klaster dimana jumlah kabupaten/kota pada klaster satu hingga empat berturut-turut adalah 7, 51, 38, dan 23 kabupaten/kota. Selain itu, berdasarkan plot $K$ Means, ditunjukkan bahwa Kabupaten Pacitan dan Kota Batu berkumpul dengan klaster DKI Jakarta. Pada umumnya, kabupaten dan kota di Jawa Barat, Jawa Tengah, dan Jawa Timur berkumpul pada satu klaster. Kemudian diketahui bahwa varians antarklaster sebesar 397,30 dan masing-masing varians dalam klaster satu hingga empat berturutturut adalah 16,$95 ; 45,97 ; 36,13$; dan 45,14 . Hal ini menunjukkan bahwa klaster yang dibentuk sudah memiliki ciri klaster yang baik, yaitu varians antarklaster tinggi (heterogen) dan varian dalam klaster rendah (homogen). Gambar persebaran kelompok-kelompok klaster yang terbentuk adalah sebagai berikut.

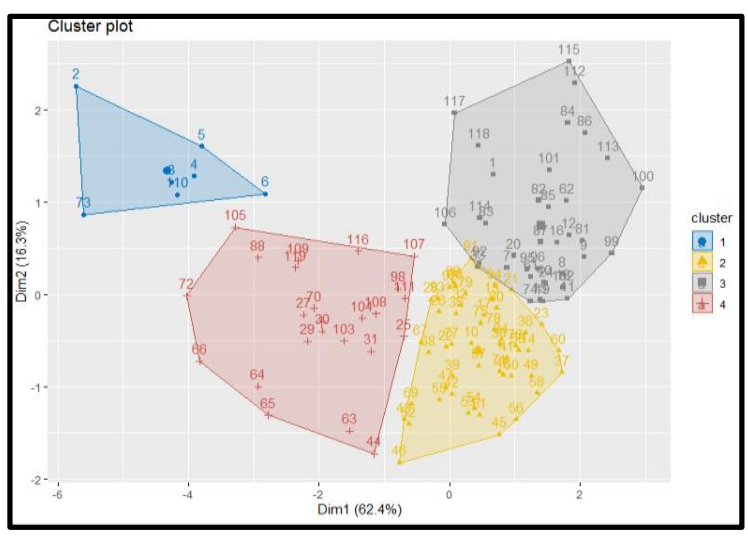

Gambar. 6 - Hasil pengelompokkan dengan metode $K$-Means

\section{Metode Fuzzy C-Means (FCM)}

Metode FCM merupakan pengembangan dari metode $K$-Means di mana keberadaan tiap titik data dalam klaster ditentukan oleh derajat keanggotaan. Penentuan jumlah klaster optimum dipilih berdasarkan silhouette plot dengan nilai silhouette terbesar. Berikut adalah hasil dari silhouette plot.

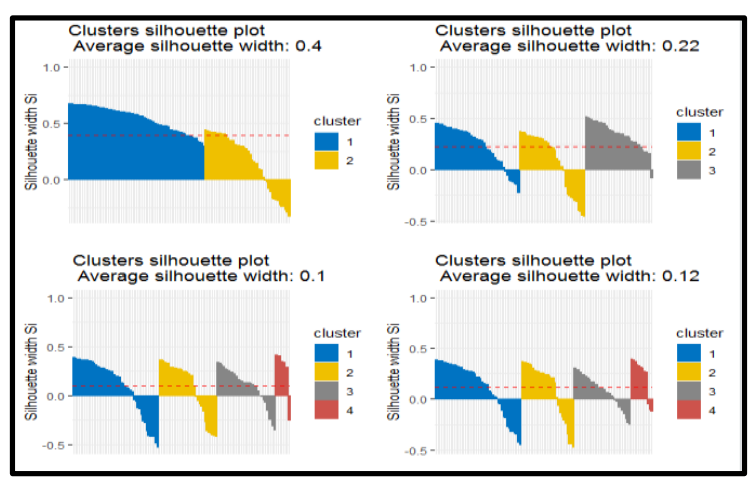

Gambar. 7 - Nilai silhouette FCM

Dalam penelitian ini didapatkan jumlah klaster optimum untuk metode FCM adalah dua buah, karena nilai silhouette-width dengan dua klaster menunjukkan hasil yang tertinggi. Sedangkan jika menggunakan lebih dari dua klaster nilai silhouettewidth mengalami penurunan. Nilai silhouette-width yang menurun mengindikasikan bahwa data tidak terklaster dengan tepat. Berikut ini merupakan gambar persebaran pengelompokkan dengan metode FCM. Klaster pertama terdiri dari 73 kabupaten/kota dan klaster kedua terdiri dari 46 kabupaten/kota. 


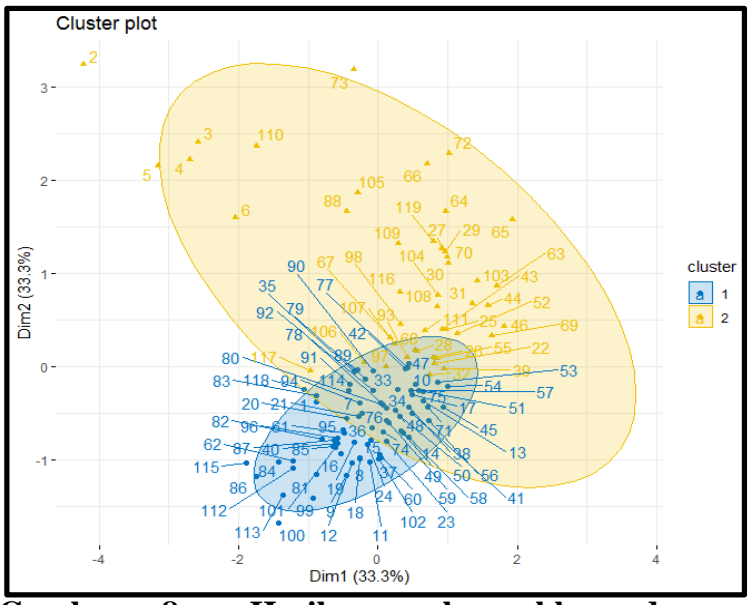

Gambar. 8 - Hasil pengelompokkan dengan metode FCM

Hard clustering merupkam suatu pendekatan dalam metode FCM, ketika suatu objek memiliki nilai keanggotaan dalam satu klaster paling besar, maka objek tersebut masuk ke dalam klasternya. Sebagai contoh, Kepulauan Seribu masuk ke dalam klaster pertama dengan nilai keanggotaan 0,57 , dan masuk ke dalam klaster dua dengan nilai keanggotaan 0,43 . Karena nilai keanggotaan pada klaster satu lebih tingi, maka Kepulauan Seribu masuk ke dalam klaster pertama.

\section{Validitas Metode Non Hirarki}

Selanjutnya adalah uji validitas metode klaster non hirarki melalui uji validitas internal. Untuk metode $K$-Means dengan jumlah klaster sebanyak empat dan metode FCM dengan jumlah klaster sebanyak dua, penghitungan dengan package clValid() aplikasi $\mathrm{R}$ hasilnya adalah sebagai berikut.

Tabel 6 - Ukuran validitas metode $K$-means dan FCM

\begin{tabular}{ccc}
\hline $\begin{array}{c}\text { Metode } \\
\text { Pengklasteran }\end{array}$ & $\begin{array}{c}\text { Ukuran } \\
\text { Validasi }\end{array}$ & Nilai \\
\hline \multirow{2}{*}{ K-means } & $(2)$ & $(3)$ \\
\hline & Connectivity & 33,07 \\
\cline { 2 - 3 } & Daunn & 0,07 \\
\cline { 2 - 3 } & Silhouette & 0,34 \\
\hline \multirow{3}{*}{ FCM } & Connectivity & 25,66 \\
\cline { 2 - 3 } & Daunn & 0,04 \\
\cline { 2 - 3 } & Silhouette & 0,4 \\
\hline
\end{tabular}

Berdasarkan Tabel 6, dapat disimpulkan bahwa hasil validitas internal menunjukkan metode FCM lebih valid dalam mengelompokkan data dibandingkan metode $K$-Means. Hal ini ditunjukkan oleh nilai validitas pada indeks connectivity yang terkecil dan nilai silhouette tertinggi ada pada metode FCM. Oleh karena itu, metode FCM dengan jumlah klaster dua, terpilih sebagai metode klaster non hirarki terbaik.

Tabel 7 - Hasil pengelompokkan dengan metode FCM.

\begin{tabular}{cl}
\hline Klaster & \multicolumn{3}{c}{ Kabupaten/Kota } \\
\hline & Kep. Seribu, Bogor, Sukabumi, Cianjur, \\
& Bandung, Garut, Tasikmalaya, Ciamis, \\
& Kuningan, Cirebon, Majalengka, \\
& Sumedang, Indramayu, Subang, \\
& Purwakarta, Karawang, Bandung Barat, \\
& Pangandaran, Kota Banjar, Cilacap, \\
& Banyumas, Purbalingga, Banjarnegara, \\
& Kebumen, Wonosobo, Magelang, \\
& Boyolali, Wonogiri, Sragen, Grobogan, \\
& Blora, Rembang, Pati, Jepara, Demak, \\
Klaster & Temanggung, Kendal, Batang, \\
1 & Pekalongan, Tegal, Pemalang, Brebes, \\
& Sleman, Ponorogo, Trenggalek, \\
& Tulungagung, Blitar, Kediri, Malang, \\
& Lumajang, Jember, Banyuwangi, \\
& Bondowoso, Situbondo, Probolinggo, \\
& Pasuruan, Sidoarjo, Jombang, Nganjuk, \\
& Madiun, Magetan, Bojonegoro, Tuban, \\
& Lamongan, Sampang, Pamekasan, \\
& Sumenep, Kota Kediri, Lebak, Tangerang, \\
& Serang, Kota Tangerang, dan Kota \\
Tangerang Selatan.
\end{tabular}

Kota Jakarta Selatan, Kota Jakarta Timur, Kota Jakarta Pusat, Kota Jakarta Barat, Kota Jakarta Utara, Bekasi, Kota Bogor, Kota Sukabumi, Kota Bandung, Kota Cirebon, Kota Bekasi, Kota Depok, Kota Cimahi, Kota Tasikmalaya, Purworejo, Klaten, Sukoharjo, Karanganyar, Kudus, Semarang, Kota Magelang, Kota Surakarta, Kota Salatiga, Kota Pekalongan, Kota Tegal, Kulon Progo, Bantul, Gunung Kidul, Kota Yogyakarta, Pacitan, Mojokerto, Ngawi, Gresik, Bangkalan, Kota Blitar, Kota Malang, Kota Probolinggo, Kota Pasuruan, Kota Mojokerto, Kota Madiun, Kota Surabaya, Kota Batu, Pandeglang, Kota Cilegon, Kota Serang, dan Kota Semarang.

\section{Profiling Hasil Analisis Klaster Non Hirarki}

Berdasarkan pengelompokkan dengan metode FCM didapatkan dua buah klaster. Berikut ini merupakan tabel rata-rata masing-masing indikator dari 
komponen utama yang telah ditransformasi kembali sesuai dengan data sebelumnya.

Tabel 8 - Nilai rata-rata setiap indikator IPM dalam klaster

\begin{tabular}{cccccc}
\hline Klaster & $\mathbf{X}_{\mathbf{1}}$ & $\mathbf{X}_{\mathbf{2}}$ & $\mathbf{X}_{\mathbf{3}}$ & $\mathbf{X}_{\mathbf{4}}$ & $\mathbf{X}_{\mathbf{5}}$ \\
\hline 1 & 9970,4 & 7,04 & 71,53 & 12,45 & 226,08 \\
\hline 2 & 13822,7 & 9,78 & 73,79 & 13,92 & 799,37 \\
\hline
\end{tabular}

Berdasarkan Tabel 8, dapat dianalisa bahwa mayoritas anggota pada klaster dua terdiri dari wilayah perkotaan. Karakteristik yang tercermin pada klaster dua ini adalah pengeluaran per kapita, ratarata lama sekolah, umur harapan hidup, harapan lama sekolah, dan jumlah dokter yang seluruhnya lebih tinggi dibandingkan klaster pertama. Hal ini sesuai dengan ciri wilayah perkotaan yang menggambarkan bahwa fasilitas pendidikan, fasilitas kesehatan, dan biaya hidup yang lebih tinggi jika dibandingkan dengan wilayah kabupaten. Wilayah kota dari masing-masing provinsi di Pulau Jawa tersebar secara merata pada klaster dua, begitu juga wilayah kabupaten masing-masing provinsi di Pulau Jawa juga tersebar merata pada klaster pertama. Jika dihitung rata-rata seluruh variabel maka klaster kedua lebih tinggi dibandingkan klaster pertama.

\section{Kesimpulan}

Berdasarkan analisis dari 119 kabupaten/kota di Pulau Jawa tahun 2018 yang telah dilakukan, dapat ditarik kesimpulan sebagai berikut.

1. Hasil pengelempokkan terbaik pada metode hirarki adalah metode average linkage dengan empat buah klaster. Dari metode pengelompokkan average linkage didapatkan bahwa klaster dengan rata-rata seluruh variabel terendah adalah klaster pertama yang terdiri dari Kepulauan Seribu, Bogor, dan 78 kabupaten/kota lainnya. Sedangkan rata-rata klaster tertinggi adalah klaster ke empat yang terdiri dari Kota Yogyakarta.

2. Pada analisis klaster non hirarki, metode FCM lebih valid jika dibandingkan metode $K$-means dalam penelitian ini. Hasilya menunjukkan bahwa dengan menggunakan metode FCM terbentuk dua klaster di mana klaster pertama mayoritas beranggotakan wilayah kota, dan klaster kedua mayoritas beranggotakan wilayah kabupaten. Hal ini berarti masih terdapat ketimpangan pada wilayah kabupaten dengan kota khususnya dari segi fasilitas dan pendidikan.

3. Secara keseluruhan, pengelompokkan antara klaster hirarki dengan klaster non hirarki memberikan hasil yang berbeda.

\section{DAFTAR PUSTAKA}

Ambarwati, Atika Nurani. (2019). Latent Class Cluster Analysis untuk Pengelompokkan Kabupaten/Kota Di Provinsi Jawa Tengah Berdasarkan Indikator Indeks Pembangunan Manusia 2017. Jurnal Variance: Journal Statistics and Its Applications.

Badan Pusat Statistik. (2019). Indeks Pembangunan Manusia 2018. Jakarta.

Badan Pusat Statistik. (2019). Provinsi Banten Dalam Angka. Banten.

Badan Pusat Statistik. (2019). Provinsi Daerah Istimewa Yogyakarta Dalam Angka. Yogyakarta.

Badan Pusat Statistik. (2019). Provinsi DKI Jakarta Dalam Angka. Jakarta.

Badan Pusat Statistik. (2019). Provinsi Jawa Barat Dalam Angka. Jawa Barat.

Badan Pusat Statistik. (2019). Provinsi Jawa Tengah Dalam Angka. Jawa Tengah.

Badan Pusat Statistik. (2019). Provinsi Jawa Timur Dalam Angka. Jawa Timur.

Badan Pusat Statistik. (2019). Tabel Dinamis: Indikator Indeks Pembangunan Manusia. www.bps.go.id (diakses pada 1 Desember 2020).

Gordon, A.D. (1999). Classification (2nd Edition). London: Chapman \& Hall.

Gudono. (2011). Analisis Data Multivariat Edisi Pertama. Yogyakarta: BPFE.

Johnson, R.A. \& Wichern, D.W. (2007). Applied Multivariate Statistical Analiysis, Sixth Edition. Prentic-Hall International: New Jersey.

Kassambara, A. (2017). Practical Guide to Cluster Analysis in R. (sthd.com)

Kusumanintyas, Clara Aulia. (2017). Analisis Klaster Untuk Pengelompokkan Kabupaten/Kota di Provinsi Papua Berdasarkan Indikator Indeks Pembangunan Manusia Tahun 2017. Jakarta: Skripsi Politeknik Statistika STIS.

Rachmatin, Dewi dan Kania Sawitri. (2012). Perbandingan Antara Metode Agglomeratif, Metode Divisif, dan Metode K-Means dalam Analisis Klaster. Jurnal Pendidikan Matematika FMIPA UPI.

Wahyuni, Sri. (2018). Pengelompokkan Kabupaten/Kota di Pulau Jawa Berdasarkan Faktor-Faktor Kemiskinan deengan Pendekatan Average Linkage Hierarchical Clustering. Jakarta: Jurnal Aplikasi Statistika dan Komputasi Statistik, V.10.1.2018. 